\title{
A COMPARATIVE STUDY OF USING CLASSWIDE PEER TUTORING TECHNIQUE AND STUDENT TEAM ACHIEVEMENT DEVISION TECHNIQUE IN TEACHING READING COMPREHENSION AT STATE SENIOR HIGH SCHOOL 1 TUALANG
}

\author{
${ }^{1}$ Sumita Erika \\ ${ }^{1}$ UIN Sultan Syarif Kasim Kasim Riau, Indonesia \\ Email: ${ }^{\text {sumita@gmail.com }}$
}

Received: 30 Oktober 2019; Accepted 28 Mei 2021; Published 31 Mei 2021

Ed 2021; 2 (1): 34-39

\begin{abstract}
ABSTRAK
Tujuan dari penelitian ini adalah untuk mengeksplorasi strategi apa yang diperlukan guru untuk proses pembelajaran yang lebih baik dalam meningkatkan pemahaman membaca siswa kelas sebelas di SMA Negeri Tualang. Ini dilakukan berdasarkan desain eksperimental yang difokuskan pada kelompok penelitian kuantitatif. Satu kelompok diambil sebagai kelompok eksperimen dan satu kelompok sebagai kelompok pembanding. Sampel terdiri dari 60 siswa yang diambil dari kelas sebelas di SMA senir negeri Tualang yang terdiri dari 30 siswa kelas XI-4 untuk kelas eksperimen 1 (Teknik Bimbingan Sebaya Kelas), 30 siswa dari kelas XI-5 untuk ini. kelompok eksperimen 2 (Teknik Prestasi Tim Siswa). Lembar observasi dan tes pemahaman bacaan digunakan dalam penelitian ini. Ada 40 item soal pilihan ganda yang digunakan untuk pre-test dan post-test. Untuk menganalisis data dilakukan perhitungan independent sample t-test dengan menggunakan SPSS 20 dengan probabilitas signifikan Ho diterima jika $\mathrm{P}<0,05$ atau tidak ada pengaruh yang signifikan setelah pemberian perlakuan, Ha diterima jika $\mathrm{P}>0,05$ atau tidak ada. pengaruh yang signifikan setelah pemberian perlakuan. Teknik Classwide Peer Tutoring mendapatkan effect size atau eta-squared sebagai berikut: Eta-squared $=0.84 \mathrm{x} 100 \%=84 \%$. Teknik Prestasi Beregu Mahasiswa mendapatkan ukuran efek atau eta-squared sebagai berikut: Eta-squared $=0,91 \times 100 \%=91 \%$. Pengaruh tertinggi berasal dari Teknik Prestasi Tim Siswa, tetapi kedua kelas tidak berbeda secara signifikan. Oleh karena itu, kedua strategi tersebut dapat meningkatkan pemahaman bacaan siswa.
\end{abstract}

Kata kunci: Teknik Classwide Peer Tutoring, Teknik Student Team Achievement, Pemahaman Membaca, Komparatif

\section{A COMPARATIVE STUDY OF USING CLASSWIDE PEER TUTORING TECHNIQUE AND STUDENT TEAM ACHIEVEMENT DEVISION TECHNIQUE IN TEACHING READING COMPREHENSION AT STATE SENIOR HIGH SCHOOL 1 TUALANG}

\begin{abstract}
The purpose of this study was to explore which strategy that required a teacher for a better learning process in improving students' reading comprehension in the eleventh grade at state senior high school Tualang. It was done based on experimental design which focused on the quantitative research group. A group were taken as experimental groups and a group as the
\end{abstract}


comparison group. The sample consisted of 60 students that were taken from the eleventh grade at state senir high school Tualang which were comprised of 30 students from XI-4class for this experimental group 1 (Classwide Peer Tutoring Technique), 30 students from XI-5 class for this experimental group 2 (Student Team Achievement Technique).Observation sheets and reading comprehension tests were used in the study. There are 40 items of multiple choice questions used for the pre-test and post-test. To analyze the data, independent sample t-test were calculated by using SPSS 20 with a significant probability of Ho was accepted if $\mathrm{P}<0.05$ or there was no significant effect after giving the treatments, $\mathrm{Ha}$ was accepted if P>0.05 or there was no significant effect after giving the treatments. Classwide Peer Tutoring Technique got the effect size or eta-squared as follows: Eta-squared $=0.84 \times 100 \%=84 \%$. Student Team Achievement Technique got the effect size or etasquared as follows: Eta-squared $=0.91 \times 100 \%=91 \%$. The highest effect was from Student Team Achievement Technique, but the two classes did not differ significantly. Therefore, the two strategies could improve the students' reading comprehension.

Keywords: Classwide Peer Tutoring Technique, Student Team Achievement Technique, reading comprehension, comparative 


\section{INTRODUCTION}

English becomes one of the compulsory subjects at schools in Indonesia. Based on the curriculum, there are four language skills that have to be mastered by the students in learning English. The four language skills are reading, listening, speaking and writing. Furthermore, Pamela (1991) points out that a person needs to master the various elements to use the language to convey thoughts, wishes, intentions, feeling and information in both spoken and written form. Reading is fluent process of readers combining information from a text and their own background knowledge to build meaning (David, 2003:68). According to Nunan (2003) reading is a set of skills that involves making sense and deriving meaning from printed words. In other to read, readers must be able to decode (sound out) the printed words and also comprehend what they read.

The Indonesian government has made an effort in English, Masters in Education curriculum by giving the English lesson from elementary school until high level education. The mastery of English subject can be known through the English standard of competence of listening, speaking, reading, and writing. One of the language skill that is very important too study as the learners is reading skill. By reading students can add their knowledge and they also can get much new information from the text. The point of most of student's problem in reading activities is about reading comprehension.

In grade of senior high school, students learn English through textbook and printed material.When they faced the text book and printed materials they deal with words that they need to understand well. Students bear to have good reading skill to comprehend every single material that they read. Whenever students do not own enough reading skill to master the material then they will just stuck there. It will be hard for the students to move on to the next material in their classroom learning process. Thus, reading becomes their needs if they want to achieve the better level of English proficiency.

Cooperative learning is one of the good learning for teaching reading comprehension, but not all of the types cooperative learning are suitable for teaching reading comprehension. There are two types of cooperative learning that suitable for teaching reading comprehension they are Student Team Achievement Devision (STAD) technique and Classwide Peer Tutoring (CPT) technique. According to Slavin (1995: 22), Student Team Achievement Devision (STAD) technique is effective for teaching reading comprehension. It is pertaining to the advantages of Student Team Achievement Division (STAD) technique, the students work together in identifying the topic of the text and interaction among students by increasing their ability to make inference of the text. According to (Lague \& Wilson, 2010), CPT is cooperative learning that can increase reading comprehension for both tutors and tutees.

Based on the phenomena above the researcher interest to examine and compare both of technique. Both of them are cooperative learning and based on theories both of them can improve reading comprehension but, according to the previous researcher there was also did not find an effective in using CPT or STAD technique.

The researcher compare two particular strategies namely Student Team Achievement Division (STAD) technique and Classwide Peer Tutoring (CPT) technique will be able to solve these problems. The Student Team Achievement Division (STAD) and to examine which one can help students effectively deal with complex reading demands. This research adressed the following research question: Is there any significant difference of reading comprehension in narrative text between students who were taught by using Classwide Peer Tutoring (CPT) Technique and Students who were taught by using Student Team Achievement Division (STAD) Technique at SMA N 1 TUALANG? 


\section{METHODOLOGY}

The design of this research is an Experimental Design that focused on Quantitative research with (pre-test and post-test) design. Two groups serve as an experimental group and the other one as comparative group. Creswell $(2009, \mathrm{p} .155)$ states that when individual are not randomly assigned, the procedure is called Quasi experiment. According to L. R Gay (2000: 364), the Quasi-experimental design involves selecting two groups difffering on some independent variables and comparing them on some dependent variables. According to L.R Gay (2000, p.349), the experimental method is a method of the reserach that can turly test hypotesis concerning with cause and effect relationship in the experimental research. The group may differ in a number of ways.

This research conducted at the SMAN 1 Tualang in Siak Regency from April up to Mei 2019. the subject of the research was the eleventh grade students of SMAN 1 Tualang. The object of this research was the difference reading comprehension of narrative text between students' was taught by using Classwide Peer Tutoring Technique and Student Team Achievement Devision (STAD) Technique. The population of this research was the eleventh grade students of SMAN 1 Tualang in the academic 2018-2019 which consist of six classes which has the same capability, two classes was chosen as the sample

The Total Sample of the Research

\begin{tabular}{|c|c|c|c|c|l|}
\hline No & Class & Male & Female & $\begin{array}{c}\text { Total of } \\
\text { Students }\end{array}$ & \multicolumn{1}{c|}{ Class } \\
\hline $\mathbf{1}$ & XI.4 & 13 & 17 & 30 & $\begin{array}{l}\text { Experiment I (Classwide Peer } \\
\text { Tutoring Technique) }\end{array}$ \\
\hline $\mathbf{2}$ & XI.5 & 8 & 22 & 30 & $\begin{array}{l}\text { Experiment II (Student Team } \\
\text { Achievement Devision } \\
\text { (STAD) Technique) }\end{array}$ \\
\hline & Total & & & $\mathbf{6 0}$ & \\
\hline
\end{tabular}

\section{RESULTS AND DISCUSSION}

Since the students' prior reading comprehension between the experimental group 1 and experimental group 2 was homogenous or equal, the research could be continued. The experimental group 1 was treated using CPT and the experimental group 2 was treated using STAD. Afterward, the students' posttest scores were analyzed using independent sample t test to find out whether there is significant difference effect using Classwide Peer Tutoring (CPT) Technique and Student Team Achievement Devision (STAD) Technique on students' reading at the eleventh grade students of SMA N 1 TUALANG.

The Analysis of Independent Sample T-test of Post-test Reading Comprehension Score between Experimental Group I and Experimental Group II.

\begin{tabular}{|c|l|l|l|l|l|l|c|}
\hline $\begin{array}{c}\text { Subj } \\
\text { ect }\end{array}$ & \multicolumn{1}{|c|}{$\begin{array}{c}\text { Research } \\
\text { Groups }\end{array}$} & Mean & $\begin{array}{c}\text { Standard } \\
\text { Deviation }\end{array}$ & N & Df & T & $\begin{array}{c}\text { Sig.(2- } \\
\text { tailed) }\end{array}$ \\
\hline $\begin{array}{l}\text { Post- } \\
\text { test }\end{array}$ & $\begin{array}{l}\text { Experimental } \\
\text { Group 1 }\end{array}$ & 72,16 & 7,50 & 30 & 58 & $-2,434$ & 0.018 \\
\hline & $\begin{array}{l}\text { Experimental } \\
\text { Group 2 }\end{array}$ & 77,33 & 8,87 & 30 & & & \\
\hline
\end{tabular}


$\mathrm{T}_{\text {observe }}$ indicates $2,434>\mathrm{T}_{\text {critical }} 2,001$ with $\mathrm{p}$ value $0,018<0,05$. Therefore, Ha1 is accepted and Hol is rejected. On the other words, there is a significant difference effect of using Classwide Peer Tutoring (CPT) Technique and Student Team Achievement Devision (STAD) Technique on students' reading at the eleventh grade students of SMA N 1 TUALANG. In addition, it is clear that the students' posttest mean score of the experimental group 2 who were treated uisng Student Team Achievment Devision (STAD) Technique is higher than the experimental group $1(77,33>72,16)$ who were taught using using Classwide Peer Tutoring (CPT) Technique . Afterward, to find out the effectivenes of the two treatments on students' reading comprehension, the effect size of the two treatments was calculated using cohen' $d$ calculator. The result of the calculation is displayed as follows:

\section{The Result of the Calculation}

\begin{tabular}{|l|c|c|}
\hline & Group 1 & Group 2 \\
\hline Mean & 72,17 & 77,33 \\
\hline Standard Deviation & \multicolumn{2}{|c|}{0,6280} \\
\hline Effect Size dCohen & \multicolumn{2}{|c|}{0,5810} \\
\hline Effect Size Glass'A & \multicolumn{2}{|c|}{0,88} \\
\hline N & \multicolumn{2}{|c|}{0,95} \\
\hline Coenfidence Coeficient & \\
\hline Coeficient Interval for dcohen & \\
\hline
\end{tabular}

Based on the calculation, it is known that the effect size of the two treatments is 0,628 , which is categorized to average effect. In detail, the interpretation of the effect size is summarized in the following table:

\section{The Interpretation of Two Groups Effect Size}

\begin{tabular}{|c|c|}
\hline Size & Interpretation \\
\hline $\mathbf{0 . 8}<\mathbf{d}<\mathbf{2 . 0}$ & Big \\
\hline $\mathbf{0 . 5}<\mathbf{d}<\mathbf{0 . 8}$ & Average \\
\hline $\mathbf{0 . 2}<\mathbf{d}<\mathbf{0 . 5}$ & Small \\
\hline
\end{tabular}

Furthermore, the difference of students' reading comprehension can be traced through the category of their reading comprehension score shown in the table below:

Table IV.17

Frequency of Students' Reading Score

\begin{tabular}{|c|c|c|c|c|c|c|}
\hline \multirow{2}{*}{ No } & \multirow{2}{*}{ Categories } & \multirow{2}{*}{ Score } & \multicolumn{2}{|c|}{ Experimental Group } & \multicolumn{2}{|c|}{ Experimental Group } \\
\cline { 3 - 6 } & & & $\mathbf{F}$ & $\mathbf{1}$ & $\mathbf{F}$ & $\mathbf{1}$ \\
\hline 1 & Very Good & $80-100$ & 8 & 26.6 & 18 & 60,0 \\
\hline 2 & Good & $66-79$ & 16 & 53.3 & 9 & 30,0 \\
\hline 3 & Mediocre & $56-65$ & 5 & 16.6 & 2 & 6,7 \\
\hline 4 & Poor & $40-55$ & 1 & 3,3 & 1 & 3,3 \\
\hline 5 & Very Poor & $0-39$ & 0 & 0 & 0 & 0 \\
\hline \multicolumn{3}{|c|}{ Total } & 30 & 100 & 30 & 100 \\
\hline
\end{tabular}

It can be seen that there were 5 categories for students' reading comprehension score in Classwide Peer Tutoring Technique and Student Team Achievement Devision (STAD) technique. In Classwide Peer Tutoring Technique, the frequency of very good category was 8 students $(26,6 \%)$, the frequency of good category was 16 students $(53,3 \%)$, the frequency of 
mediocre was 5 students $(16,6 \%)$, the frequency of poor category was 1 student (3\%) and 0 for poor category. Meanwhile, In Student Team Achievement Devision (STAD) technique, the frequency of very good category was 18 students $(60,0 \%)$, the frequency of good category was 9 students $(30 \%)$, the frequency of mediocre was 2 students $(6,7 \%)$, the frequency of poor category was 1 student $(6,7 \%)$ and 0 for poor category. From the explanation above, it can be concluded that in Classwide Peer Tutoring (CPT) technique was students' reading comprehension tends to be categorized into good category and in the Student Team Achievement Devision (STAD) technique was students' reading comprehension tends to be categorized into very good category.

\section{CONCLUSSION}

There was no significant difference of students' reading comprehension pre-test mean scores between the experimental class 1 and the experimental class 2 . In brief, the students both in the experimental class 1 and in the experimental class 2 had equal ability in reading comprehension before getting a treatment. After a different treatment given to the experimental group 1 and experimental group 2, it is found that STAD technique had more effect on students' reading comprehension than CPT tecnique at the eleventh grade students of SMA N 1 TUALANG. STAD technique was more effective than CPT technique in improving the students' reading comprehension. In detail, the data description showed that the students who were taught using STAD Technique has higher score than ones who were taught using CPT technique especially for indicator of identifying main idea, locating meaning of vocabulary in context, identifying reference, and making inference.Based on the students' score, the students who were taught using CPT still had trouble in making inference, which was categorized to poor.

\section{REFERENCES}

Nunan, D. (2008). Practical English Language Teaching. Sydney: McGraw Hill.

2003. Practical English Language Teaching: Young Learners. $1^{\text {st }}$ Ed. New York: Mcgraw-Hill Companies Inc.

Slavin, R. E. (2005).Cooperative learning: teori, riset, dan praktik. Bandung: Nusa Media.

Slavin, R. E. 1995. Cooperative Learning Theory, Research and Practice. $2^{\text {nd }}$ Ed. Massachusetts: Allyn \& Bacon

Creswell, J.W. (2012). Research Design Qualitative, Quantitative And Mixed Method Approaches (2nd Edition) Thousand Oaks. Ca: Sage Publication.

Gay, L.R. (2000). Educational Research.Competencies for Analysis and Application.USA: Menril Publishing Company.

Gay, L.R. (2006). Educational Research. Competencies for Analysis and Application. USA: Menril Publishing Company. 